\title{
Assessment of Heavy Metals Pollution in Sediments from Reservoirs of the Olt River as Tool for Environmental Risk Management
}

\author{
MIHAELA IORDACHE ${ }^{1}$, ANDREEA MARIA IORDACHE ${ }^{1}$, CLAUDIA SANDRU ${ }^{1}$, CEZARA VOICA ${ }^{2}$, \\ RAMONA ZGAVAROGEA ${ }^{1}$, MARIUS GHEORGHE MIRICIOIU ${ }^{1 *}$, ROXANA ELENA IONETE ${ }^{*}$ * \\ ${ }^{1}$ National Research and Development Institute for Cryogenics and Isotopic Technologies - ICSI Rm. Vâlcea, 4 Uzinei \\ Str., 240050, Râmnicu Vâlcea, Romania \\ ${ }^{2}$ National Institute for Research and Development of Isotopic and Molecular Technologies, 67-103 Donat Str., 400290, \\ Cluj-Napoca, Romania
}

\begin{abstract}
Heavy metals are among the most persistent pollutants in the ecosystem due to their resistance at decomposition in natural condition. They have low solubility in water and tend to be adsorbed and accumulated on bottom sediments. Anthropogenic actions conduct to the discharge of heavy metals from various sources (industrial, urban, and/or agriculture) to rivers water that are ultimately immobilized in marine sediments under current action. In this work, an investigation of pollution and ecological risk in the Olt River waters is performed based on assessing the accumulation of heavy metals in sediments. Therefore, sediment samples were collected from 22 locations on the Olt River, in its middle and lower basin, and investigated by inductively coupled plasma mass spectrometry which allows us to measure very low elements concentration levels. Two main aspects were foreseen in this study: (i) determining the content and spatial distribution of heavy metals in the Olt River surface sediments, and (ii) assessing the pollution level based on various parameters, namely the contamination factor, the geo-accumulation, pollution load and Nemerow pollution indexes, the potential ecological risk, and risk assessment code. This methodology proves to be an appropriate tool to apply in decision-making on environmental risk management.
\end{abstract}

Keywords: heavy metals, ecological risk, pollution, ecosystem, sediments

Because of industrial growth and development, water environments are increasingly exposed to heavy metal pollutants, which are a serious threat for the aquatic ecosystem, such as water, sediments and biota, because of their environmental persistence, bioaccumulation and ability to be incorporated into the food chain. Heavy metals are deposited in sediment by adsorption, hydrolysis and co-precipitation processes, causing a potential risk to aquatic biota and human health $[1,2]$.

In aquatic environment, heavy metals are distributed among aqueous phase, suspended particles and sediments. Suspended particles plays an important role controlling the reactivity, transport and biological impact of metals and other substances in the aquatic environment and provide a crucial link for chemical constituents between water column, bed sediments and food chain [3]. Generally, more than $90 \%$ of trace metals are bound to suspended solids and sediments, leading to their significant accumulation and enrichment in sediment in aquatic systems [4].

Riverine sediment is an important sink for trace metals in river basins because of the deposition of suspended or dissolved metals inputted by surface runoff and direct anthropogenic discharges. However, riverine sediment can also be a source of trace metals for river water as a result of environmental changes (e.g., $\mathrm{pH}$ and redox) at the sediment overlying water interface. For example, a decrease in redox at the interface between solid and liquid phases would facilitate reductive dissolution of Fe and Mn oxides, which lead to the release of trace metals that were bound to them. Also, low $\mathrm{pH}$ reduces the negative surface charges of sediment particles and $\mathrm{Fe}$ and $\mathrm{Al}$ oxides, promoting the solubility, mobility and bioavailability of metals co-precipitated with carbonates and sulfides [4-6].

In polluted habitats, heavy metals may accumulate in the aquatic ecosystems, especially in fish tissues, which, in turn, may enter into the human food chain and eventually lead to health risks. Heavy metals and metalloids discharged into an aquatic system by both anthropogenic and natural sources are distributed between different compartments of these ecosystems, such as water, sediment and biota. Once entered into the aquatic ecosystem, only a small portion of free metal ions remain dissolved in water because of the particularities of heavy metals and metalloids, the rest getting deposited in the sediments [7]. Thus, trace metals are widely distributed in the environment. Nevertheless, sewage waters and sludge directly discharged by wastewater treatment plants (WWTP) also represent major sources of contamination in lakes $[5,8]$.

The lake sediments are basic components of our environments as they provide nutrients for living organism. Lakes bottom sediments are sensitive indicators for monitoring contaminants since they can act as a sink and carrier for 
pollutants in the aquatic environment. Therefore, the lake sediment analysis plays an important role in evaluating pollution status in aquatic environment [9].

*email: marius.miricioiu@icsi.ro; roxana.ionete@icsi.ri

The main aspects of the present work are to investigate the spatial distribution characteristics of heavy metals $(\mathrm{Cd}$, $\mathrm{Cu}, \mathrm{Ni}, \mathrm{Zn}, \mathrm{Pb}, \mathrm{Cr}, \mathrm{Hg}$ ) in the Olt River surface sediments and to evaluate the heavy metals contamination using specific indices, namely the contamination factor (CF), the geo-accumulation index (Igeo), the pollution load index (PLI), the Nemerow pollution index (PI), potential ecological risk (RI), and the risk assessment code (RAC).

\section{Experimental part}

Materials and method

Study area

The Olt River, with a total length of $615 \mathrm{~km}$, flows into the Danube River near Turnu Magurele, Islaz. The middle and lower part of the Olt River's catchment includes 19 lakes, for electricity production and/or irrigation purposes. The average flow of the Olt River is $140 \mathrm{mc} / \mathrm{s}$ with monthly variations from 25 to $300 \mathrm{mc} / \mathrm{s}$. The largest amount of the annual flow volume of the Olt River is registered in May, when the snows melts in the mountains and abundant spring rains occur; it often exceeds several times the average annual flow. The maximum recorded at Râmnicu Vâlcea reached 2580 $\mathrm{m}^{3} / \mathrm{s}$. The lowest flows are registered in September and October after the period of minimum precipitation and evaporation in August and September and strong before winter maximum rainfall event.

The sediments samples were collected in 22 points (Figure 1), including 19 accumulation lakes, 1 point from the Olt River before flowing into the Danube River and 2 points in the Danube River - upstream and downstream of the Olt River (Table $1)$.

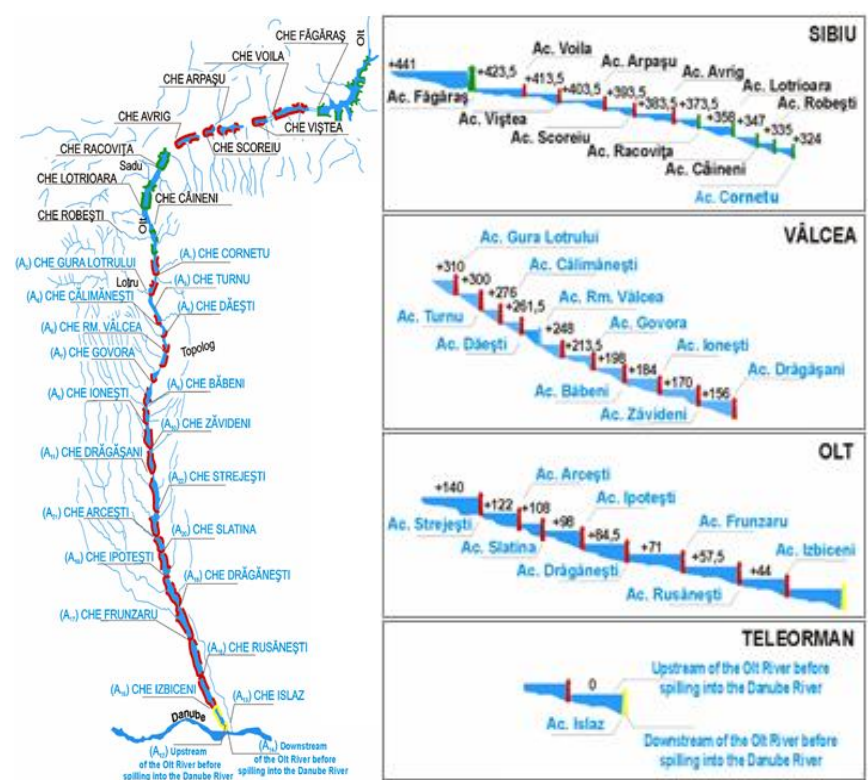

Fig. 1. Location of sampling points (marked in blue) on the Olt River in its middle and lower basin

Table 1

DESCRIPTION OF SEDIMENT SAMPLING POINTS ON THE OLT RIVER

\begin{tabular}{|ccc|}
\hline $\begin{array}{c}\text { Sample } \\
\text { code }\end{array}$ & $\begin{array}{c}\text { Coordinates } \\
\text { (longitude and latitude) }\end{array}$ & Sediment samples - sampling point \\
\hline $\mathrm{A}_{1}$ & $\mathrm{~N}: 45^{\circ} 24^{\prime} 337 ; \mathrm{E}: 24^{\circ} 18^{\prime} 255$ & Cornetu accumulation lake, Vâlcea county \\
$\mathrm{A}_{2}$ & $\mathrm{~N}: 45^{\circ} 21^{\prime} 312 ; \mathrm{E}: 24^{\circ} 16^{\prime} 350$ & Lotru accumulation lake, Vâlcea county \\
$\mathrm{A}_{3}$ & $\mathrm{~N}: 45^{\circ} 17^{\prime} 200 ; \mathrm{E}: 24^{\circ} 18^{\prime} 365$ & Turnu accumulation lake, Vâlcea county \\
$\mathrm{A}_{4}$ & $\mathrm{~N}: 45^{\circ} 14^{\prime} 522 ; \mathrm{E}: 24^{\circ} 20^{\prime} 855$ & Călimăneşti accumulation lake, Vâlcea county \\
$\mathrm{A}_{5}$ & $\mathrm{~N}: 45^{\circ} 10^{\prime} 723 ; \mathrm{E} 24^{\circ} 22^{\prime} 200$ & Dăeşti accumulation lake, Vâlcea county \\
$\mathrm{A}_{6}$ & $\mathrm{~N}: 45^{\circ} 07^{\prime} 510 ; \mathrm{E}: 24^{\circ} 22^{\prime} 382$ & Râmnicu Vâlcea accumulation lake, Vâlcea county \\
$\mathrm{A}_{7}$ & $\mathrm{~N}: 45^{\circ} 00^{\prime} 542 ; \mathrm{E}: 24^{\circ} 17^{\prime} 922$ & Govora accumulation lake, Vâlcea county \\
$\mathrm{A}_{8}$ & $\mathrm{~N}: 44^{\circ} 55^{\prime} 030 ; \mathrm{E}: 24^{\circ} 14^{\prime} 983$ & Băbeni accumulation lake, Vâlcea county \\
$\mathrm{A}_{9}$ & $\mathrm{~N}: 44^{\circ} 51^{\prime} 468 ; \mathrm{E}: 24^{\circ} 16^{\prime} 927$ & Ioneşti accumulation lake, Vâlcea county \\
$\mathrm{A}_{10}$ & $\mathrm{~N}: 44^{\circ} 46^{\prime} 620 ; \mathrm{E}: 24^{\circ} 16^{\prime} 935$ & Zăvideni accumulation lake, Vâlcea county \\
$\mathrm{A}_{11}$ & $\mathrm{~N}: 44^{\circ} 07^{\prime} 790 ; \mathrm{E}: 24^{\circ} 17^{\prime} 888$ & Drăgăşani accumulation lake, Vâlcea county \\
$\mathrm{A}_{12}$ & $\mathrm{~N}: 43^{\circ} 42^{\prime} 693 ; \mathrm{E}: 24^{\circ} 46^{\prime} 610$ & Danube River - upstream the Olt River, Teleorman county \\
$\mathrm{A}_{13}$ & $\mathrm{~N}: 43^{\circ} 44^{\prime} 630 ; \mathrm{E}: 24^{\circ} 46^{\prime} 777$ & Olt River - Islaz, before flowing into the Danube River, Teleorman \\
$\mathrm{A}_{14}$ & $\mathrm{~N}: 43^{\circ} 42^{\prime} 792 ; \mathrm{E}: 24^{\circ} 53^{\prime} 463$ & Danube River - downstream the Olt River, Teleorman county \\
$\mathrm{A}_{15}$ & $\mathrm{~N}: 43^{\circ} 48^{\prime} 682 ; \mathrm{E}: 24^{\circ} 42^{\prime} 318$ & Izbiceni accumulation lake, Olt county \\
$\mathrm{A}_{16}$ & $\mathrm{~N}: 43^{\circ} 54^{\prime} 772 ; \mathrm{E}: 24^{\circ} 37^{\prime} 680$ & Rusăneşti accumulation lake, Olt county \\
$\mathrm{A}_{17}$ & $\mathrm{~N}: 43^{\circ} 54^{\prime} 988 ; \mathrm{E}: 24^{\circ} 37^{\prime} 463$ & Frunzaru accumulation lake, Olt county \\
$\mathrm{A}_{18}$ & $\mathrm{~N}: 44^{\circ} 09^{\prime} 468 ; \mathrm{E}: 24^{\circ} 28^{\prime} 415$ & Drăgăneşti accumulation lake, Olt county
\end{tabular}


Samples collection and chemical analysis

Samples preparation

Sediments samples were collected into plastic bags, and preserved by adding a small amount of concentrated nitric acid. Samples were air-dried and after mixed to achieve homogeneity and sieved $(<0.2 \mathrm{~mm})$. Before the analysis, a digestion process was applied to the sediment samples to bring them into solution. Thus, the studied sediments samples were subjected to microwave assisted of nitric, chlorhydric and fluorhydric acids digestion. A closed iPrep vessels speed iwaveJ system MARS6 CEM One Touch was used for this procedure. Approximately $0.5 \mathrm{~g}$ aliquot of each sample was weighed, followed by digestion in mixture of ( $3 \mathrm{~mL}$ nitric acid $69 \%+2 \mathrm{ml} \mathrm{HCl} 38 \%+5 \mathrm{ml} \mathrm{HF} 40 \%)$ at high pressure, temperature and the combination of microwave.

After, the vessel is tightly closed and placed on the rotor, the microwave temperature is increased up to $200{ }^{\circ} \mathrm{C}$, during 6 minutes, and maintained at this level for 20 minutes. At the end of the digestion process, the vessels were cooled and carefully opened. Each digest was transferred quantitatively with ultra-pure water to a $50 \mathrm{ml}$ volumetric flask. These solutions were analyzed by ICP-MS after appropriate dilution, using external standard calibration.

\section{Analytical procedure}

The analytical methods used to environmental monitoring have greatly evolved. Inductively coupled plasma mass spectrometer offers fast multielement capabilities, a high dynamic range, and excellent detection limits in a large number of matrices. It can be used for a variety of aqueous samples like natural waters or environmental samples that can be dissolved $[10,11]$. The mass spectrometry with inductively coupled plasma (ICP-MS) is among the most successful existing methods applied when concentrations of trace and ultra-trace elements (under ppb) are envisaged [12]. For this work, measurements were performed with an inductively coupled plasma mass spectrometer (ICP-MS Varian 820-MS from Varian, Australia) equipped with a SPS-3 autosampler (Varian, Australia), a micro-concentric nebulizer, nickel cones, and a peristaltic sample delivery pump, running a quantitative analysis mode. Each sample was analyzed in duplicate, and each analysis consisted of ten replicates. The gaseous argon used to form the plasma in the ICP-MS was of purity 6.0 (Messer, Austria). High purity ICP Multi Element Standard Solution XXI CertiPUR obtained from Merck (Darmstadt, Germany) was used for the calibration curve in the quantitative analysis. The ICP Multi Element Standard Solution XXI CertiPUR was a mixture of $10.0 \mathrm{mg} / \mathrm{L}$ of As, Be, Bi, Co, Cr, Cu, K, Li, In, Tl, Se, Rb and V, $10.1 \mathrm{mg} / \mathrm{L}$ of $\mathrm{U}, \mathrm{Mg}, \mathrm{Ni}$, and $\mathrm{Ba}$ and $9.9 \mathrm{mg} / \mathrm{L}$ of $\mathrm{Al}, \mathrm{Cd}, \mathrm{Fe}, \mathrm{Ag}, \mathrm{Ni}$ and $\mathrm{Zn} . \mathrm{HNO}_{3} 69 \%$ (w/v), concentrated $\mathrm{HF}$ and $\mathrm{HCl}$, reagent grade from Merck and ultrapure water with a maximum resistivity of $18.2 \mathrm{MX} \mathrm{cm}^{-1}$, obtained from a Milli-Q Millipore system (Bedford, MA, USA) were used for sample treatment and sample dilution.

The performance of an ICP-MS Varian 820 instrument strongly depends on the operating conditions. Working parameters for plasma were chosen so as to obtain a good compromise between high sensitivity and low oxide levels. The following instrumental parameters of ICP-Q-MS spectrometer were set: $1.0 \mathrm{~L} \mathrm{~min}^{-1}$ nebulizer gas flow (NEB); 1.2 $\mathrm{L} \mathrm{min}^{-1}$ auxiliary gas flow (AGF); $18 \mathrm{~L} \mathrm{~min}^{-1}$ plasma gas flow (PGF); $1400 \mathrm{~W}$. ICP RF Power.

\section{Assessment method of sediment contamination}

For assessing the pollution degree with heavy metals in sediments, six parameters have been used: the contamination factor $(C F)$, the geo-accumulation index $\left(I_{g e o}\right)$, the pollution load index $(P L I)$, the Nemerow pollution index $(P I)$, the potential ecological risk $(R I)$, and the risk assessment code $(R A C)$.

Contamination factor $(C F)$. Used to determine the contamination status of sediments, this parameter was calculated (Eq.1) as ratio between the concentration of each heavy metal in the sediment $\left(C_{n}\right)$ and the concentration in background $\left(B_{n}\right)$.

$$
C F=\frac{C_{n}}{B_{n}}
$$

For the investigated heavy metals, namely $\mathrm{As}, \mathrm{Ni}, \mathrm{Cd}, \mathrm{Cu}, \mathrm{Pb}, \mathrm{Zn}, \mathrm{Cr}$ and $\mathrm{Hg}$, the background value $\left(B_{n}\right)$ in sediment is $29,35,0.8,40,85,150,100$ and $0.3 \mathrm{mg} / \mathrm{kg}$, respectively [13]. Depending on its value, the sediment pollution degree is classified as shown in Table 2.

Table 2

CONTAMINATION LEVELS OF SEDIMENTS ACCORDING TO VALUES OF CONTAMINATION FACTOR

\begin{tabular}{|cc|}
\hline Contamination factor $(C F)$ & Contamination level \\
\hline$C F<1$ & Low \\
$1 \leq C F<3$ & Moderate \\
$3 \leq C F<6$ & Considerable \\
$C F>6$ & Very high \\
\hline
\end{tabular}


Geoaccumulation index $\left(I_{g e o}\right)$. The concept of geoaccumulation index $\left(\mathrm{I}_{\mathrm{geo}}\right)$ was proposed by Muler, in 1979 [1, 14 , 15], as method to quantify metal pollution in aquatic sediments (Eq. 2):

$$
I_{\text {geo }}=\log _{2}\left[\frac{C_{n}}{1.5 B_{n}}\right]
$$

where $C_{n}$ is the concentrations of the heavy metal in sediment; and $B_{n}$ is the background value in sediment. According to the $I_{g e o}$ values, categories of contamination levels were defined in Table 3.

Table 3

RELATION BETWEEN $I_{g e o}$ AND POLLUTION LEVEL

\begin{tabular}{|ccc|}
\hline$I_{\text {geo }}$ value & Class relative to Igeo $_{\text {ge }}$ & Pollution level \\
\hline$\leq 0$ & 0 & Non-polluted \\
$0-1$ & 1 & Non-polluted to moderate polluted \\
$1-2$ & 2 & Moderate polluted \\
$2-3$ & 3 & Moderate to strong polluted \\
$3-4$ & 4 & Strong polluted \\
$4-5$ & 5 & Strong to very strong polluted \\
$\geq 5$ & 6 & Very strong polluted \\
\hline
\end{tabular}

Pollution load index (PLI). Pollution load index (PLI) is calculated as the following equation (3):

$$
P L I=\left(C F_{1} \cdot C F_{2} \cdot C F_{3} \cdot \ldots C F_{n}\right)^{1 / n}
$$

where,$n$ " is the number of metals, and $C F$ is the contamination factor.

The $P L I$ provides simple but comparative means for assessing a site quality, where a value of $P L I<1$ denotes perfection; $P L I=1$ presents that only baseline levels of pollutants are presented and $P L I>1$ would indicate deterioration of site quality.

Nemerow pollution index (PI). The Nemerow pollution index $(P I)[9,14]$, (Eq. 4) was used to determine whether or not sampling sites were polluted in comparison with the criteria given in Table 4.

$$
P I=\sqrt{\frac{(\overline{C F})^{2}+(C F \max )^{2}}{2}}
$$

Table 4

NEMEROW POLLUTION INDEX SEDIMENT QUALITY INDICATORS

\begin{tabular}{|cc|}
\hline PI value Qualification of sediment & $\begin{array}{c}\text { PI value Qualification } \\
\text { of sediment }\end{array}$ \\
\hline$P I<0.7$ & Non-polluted sediment \\
$0.7<P I<1$ & Nearly polluted sediment \\
$1<P I<2$ & Lightly polluted sediment \\
$2<P I<3$ & Moderately polluted sediment \\
$3<P I$ & Seriously polluted sediment \\
\hline
\end{tabular}

Potential ecological risk (RI)

In 1980, Lars Hakanson reported an ecological risk index for aquatic pollution control, and its method has been often used in ecological risk assessment as a diagnostic tool to penetrate one of many possible avenues towards a potential ecological risk index, i.e. to sort out which drainage area, reservoir, and substances should be given special attention (Tables 5-6) [9, 16, 17, $18,19,20,21,22]$.

The index is calculated using the following equations (5) - (8):

$$
\begin{aligned}
& C H=\sum_{i=1}^{n} C F \\
& m_{C H}=\frac{\sum_{i=1}^{n} C F}{n} \\
& E_{f}=T_{f} \cdot C F \\
& R I=\sum_{i=1}^{n} E_{f}
\end{aligned}
$$

where $C F$ is the metal contamination factor, $C H$ represent the degree of contamination and is defined as the sum of all contamination factors, $m_{C H}$ is the degree of contamination modified extraction of a final degree of contamination based on available contaminant determinations, $E_{f}$ is a potential environmental risk factor of the metal, and $T_{f}$ is the biological toxicity factor of individual metals, which are defined as 30 for $\mathrm{Cd}, 2$ for $\mathrm{Cr}, 5$ for $\mathrm{Cu}$ and $\mathrm{Pb}, 6$ for $\mathrm{Ni}, 1$ for $\mathrm{Zn}, 40$ for $\mathrm{Hg}$, and 10 for As. 
Table 5

THE DEGREE OF CONTAMINATION (CH), THE MODIFIED CONTAMINATION $\left(M_{C H}\right)$ AND CONTAMINATION LEVEL

\begin{tabular}{|c|c|c|}
\hline & & Contamination level \\
\hline 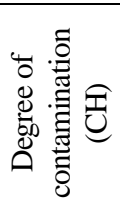 & $\begin{array}{l}C H<7 \\
7<C H<14 \\
14<C H<28 \\
C H>28\end{array}$ & $\begin{array}{c}\text { according to Hakanson (1980) } \\
\text { low } \\
\text { moderate } \\
\text { considerable } \\
\text { very high }\end{array}$ \\
\hline 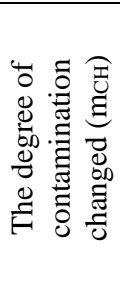 & $\begin{array}{l}0<m_{C H}<1.5 \\
1.5 \leq m_{C H}<2 \\
2<m_{C H}<4 \\
4<m_{C H}<8 \\
8<m_{C H}<16 \\
16<m_{C H}<32 \\
m_{C H}>32\end{array}$ & $\begin{array}{c}\text { according to Abrahim and Parker (2008) } \\
\text { very low } \\
\text { low } \\
\text { moderate } \\
\text { high } \\
\text { very high } \\
\text { extremely high } \\
\text { very extremely high }\end{array}$ \\
\hline
\end{tabular}

Table 6

GRADE STANDARD OF $E_{f}$ AND $R I$ [9]

\begin{tabular}{|lll|}
\hline Pollution coefficient $($ Ef) & Pollution index $($ RI $)$ & Pollution level \\
\hline$<40$ & $<150$ & Light ecological risk \\
\hline $40-79$ & $150-299$ & Middle ecological risk \\
\hline $80-159$ & $300-600$ & Strong ecological risk \\
\hline $160-320$ & $>600$ & Very strong ecological risk \\
\hline$>320$ & - & Extremely strong ecological risk \\
\hline
\end{tabular}

Risk assessment code (RAC). The risk assessment code (RAC) was developed to estimate the environment risk of heavy metals by applying a scale to the percentage of metals presented in the acid soluble/exchangeable fraction (F1) [1, 23, 24]. The classification of the $R A C$ for assessing metal pollution was expressed as the percentage of acid soluble fraction in sediment (Table 7).

Table 7

CLASSIFICATION OF THE RAC

\begin{tabular}{|c|c|c|}
\hline Class & Acid soluble \% & Risk amplitude \\
\hline 1 & $<1$ & no risk \\
2 & $1-10$ & low risk \\
3 & $11-30$ & medium risk \\
4 & $31-50$ & high risk \\
5 & $>50$ & very high risk \\
\hline
\end{tabular}

\section{Results and discussions}

\section{Heavy metal concentrations}

The total concentration of heavy metals for each sampling site found in sediments of the Olt River are highlight in Fig. 2 and Table 8. Considering the registered values in the investigated areal, the following hierarchy of the metals was obtained, from higher to lower mean content, $\mathrm{As}>\mathrm{Zn}>\mathrm{Ni}>\mathrm{Cr}>\mathrm{Pb}>\mathrm{Cu}>\mathrm{Cd}>\mathrm{Hg}$. For As, the results reveal high concentration values, exceeding the admissible limits imposed by the law [13] of $29 \mathrm{mg} / \mathrm{kg}$ in most of the sampling locations, except for A3, A8, A12 and A19. Also, a higher load with mercury was found in sections A8, A9, A10, A11 (downstream of the Râmnicu Vâlcea chemical platform), the values obtained in these sections, from 0.33 to $1.11 \mathrm{mg} / \mathrm{kg}$, exceeding the limit value of 0.3 $\mathrm{mg} / \mathrm{kg}$ set by legislation. For $\mathrm{Zn}, \mathrm{Cr}, \mathrm{Cu}$ and $\mathrm{Pb}$ the values were within the limits. Important accumulations of $\mathrm{Ni}$ was registered in sediments across the middle basin of the Olt River during the observations (Fig. 2).
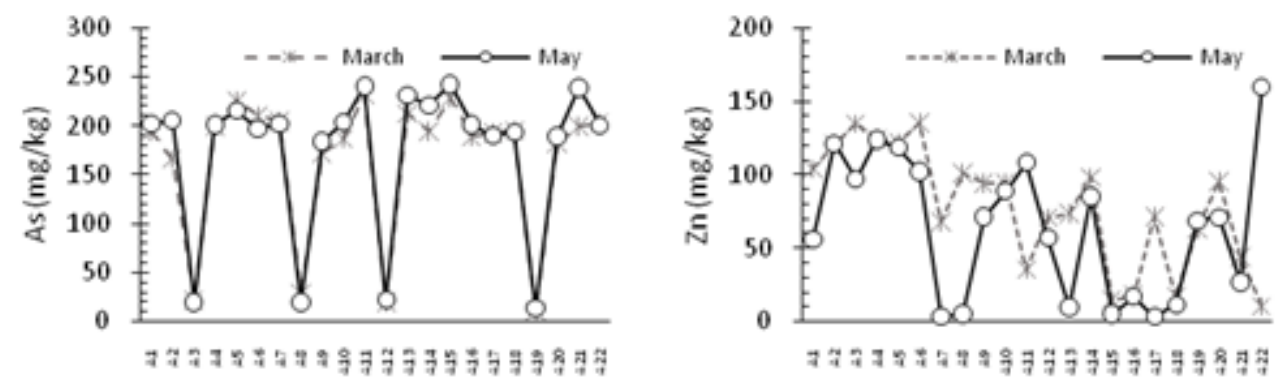

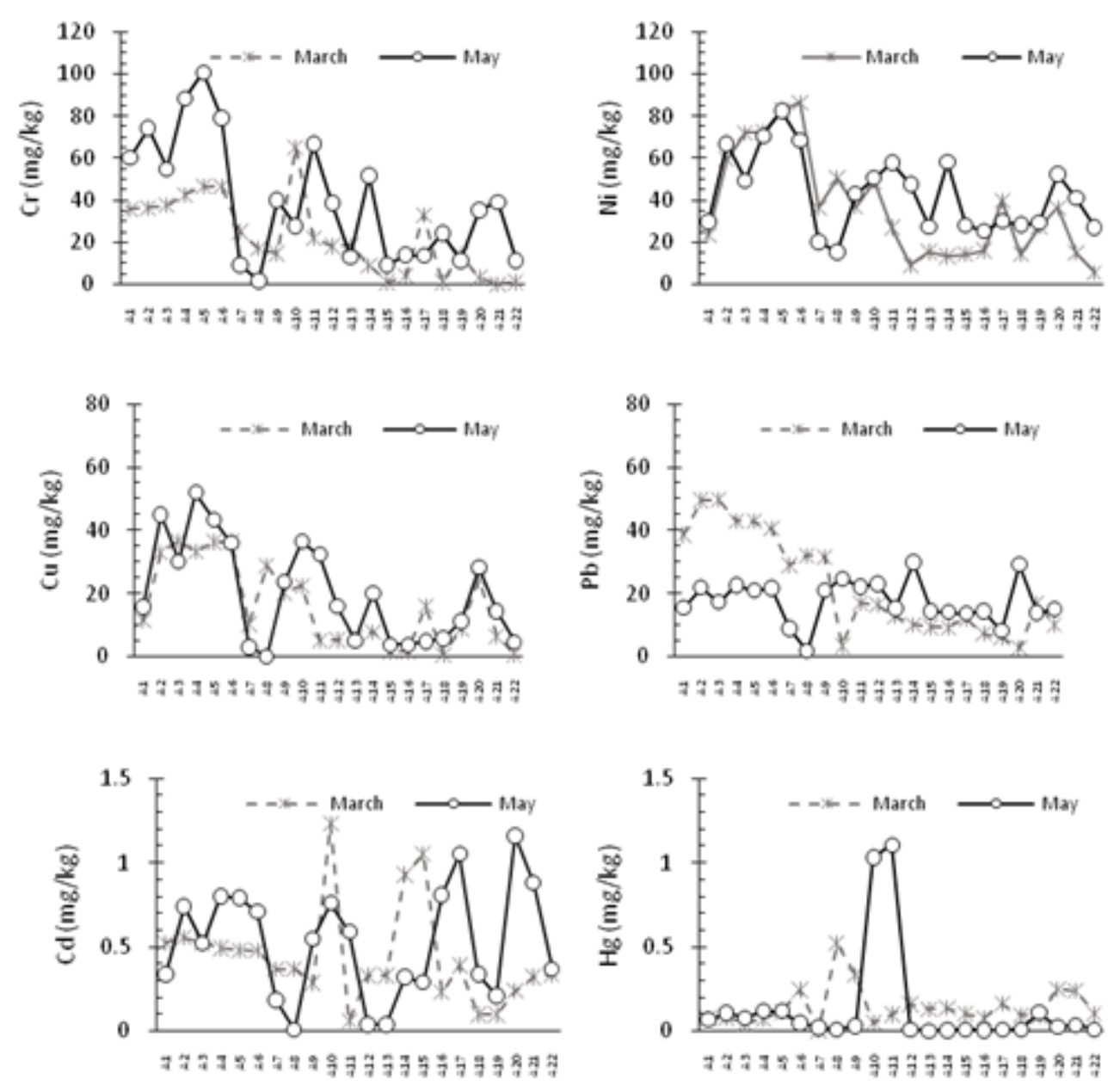

Fig. 2. Concentrations of heavy metals in sediments of the Olt River

Table 8

THE CONTENT OF HEAVY METALS IN SEDIMENTS OF THE OLT RIVER, DURING THE MONITORING PERIOD

\begin{tabular}{|c|cccccccc|}
\hline March-May & \multicolumn{7}{|c|}{ Quality indicators analyzed, in [mg/kg] } \\
\cline { 2 - 9 } 2018 & $Z n$ & $C r$ & $C u$ & $N i$ & $P b$ & $A s$ & $C d$ & $H g$ \\
\hline Minimum & 3.20 & 0.090 & 0.125 & 5.68 & 1.74 & 10.0 & 0.008 & 0.01 \\
Maximum & 160.0 & 100.66 & 52.02 & 86.31 & 49.63 & 242.13 & 1.230 & 1.105 \\
Mean & 70.9 & 30.86 & 17.93 & 39.82 & 20.0 & 170.47 & 0.48 & 0.14 \\
Std. dev. & 44.3 & 25.46 & 14.54 & 21.90 & 12.3 & 73.98 & 0.14 & 0.228 \\
\hline
\end{tabular}

Pearson's correlation coefficient matrix among the selected heavy metals of Olt River sediments is presented in Table 9. Significant correlations between the contaminants like 0.917 for $\mathrm{Cr}-\mathrm{Ni}, 0.801$ for $\mathrm{Cu}-\mathrm{Cr}, 0.783$ for Ni-Cr, 0.762 for $\mathrm{Cu}-\mathrm{Zn}, 0.695$ for $\mathrm{Ni}-\mathrm{Zn}, 0.600$ for $\mathrm{Pb}-\mathrm{Zn}$, and 0.572 for $\mathrm{Cr}-\mathrm{Zn}$, could indicate the same or similar source input.

Table 9

CORRELATION MATRIX BETWEEN HEAVY METALS IN SEDIMENT SAMPLE FROM THE OLT RIVER

\begin{tabular}{|c|c|c|c|c|c|c|c|c|}
\hline & $\mathrm{Zn}$ & $\mathrm{Cr}$ & $\mathrm{Cu}$ & $\mathrm{Ni}$ & $\mathrm{Pb}$ & $\mathrm{As}$ & $\mathrm{Cd}$ & $\mathrm{Hg}$ \\
\hline $\mathrm{Zn}$ & 1 & 0.572 & 0.762 & $\mathbf{0 . 6 9 5}$ & $\mathbf{0 . 6 0 0}$ & -0.079 & 0.237 & 0.257 \\
\hline $\mathrm{Cr}$ & $\mathbf{0 . 5 7 2}$ & 1 & 0.801 & $\mathbf{0 . 7 8 3}$ & 0.364 & 0.145 & 0.409 & 0.091 \\
\hline $\mathrm{Cu}$ & $\mathbf{0 . 7 6 2}$ & $\mathbf{0 . 8 0 1}$ & 1 & $\mathbf{0 . 9 1 7}$ & 0.594 & 0.014 & 0.383 & 0.324 \\
\hline $\mathrm{Ni}$ & $\mathbf{0 . 6 9 5}$ & $\mathbf{0 . 7 8 3}$ & 0.917 & 1 & 0.668 & 0.065 & 0.315 & 0.170 \\
\hline $\mathrm{Pb}$ & $\mathbf{0 . 6 0 0}$ & 0.364 & 0.594 & 0.668 & 1 & 0.019 & 0.113 & 0.119 \\
\hline $\mathrm{As}$ & -0.079 & 0.145 & 0.014 & 0.065 & 0.019 & 1 & 0.309 & 0.063 \\
\hline $\mathrm{Cd}$ & 0.237 & 0.409 & 0.383 & 0.315 & 0.113 & 0.309 & 1 & 0.075 \\
\hline $\mathrm{Hg}$ & 0.257 & 0.091 & 0.324 & 0.170 & 0.119 & 0.063 & 0.075 & 1 \\
\hline
\end{tabular}

Assessment of sediment contamination

A common criterion to evaluate the heavy metal pollution in sediments are the indicators: Contamination Factor (CF), Geo-Accumulation Index (Igeo), Ecological Risk Index (RI), Pollution Index (PLI), Pollution Nemerow (PI) and Risk Assessment Code (RAC). 


\section{Contamination factor (CF)}

Variations in the $C F$ s of different metals in sediments from the Olt river at different times (Fig. 3), reflect the level of contamination. According to the data, the $A s$ posses the highest $C F \mathrm{~s}$ in almost all the sampling areals, with values from 5.72 to 8 in March campaign and 6.34 to 8.35 in May (reflecting considerably and highly contaminated sediments), except for A3 (0.74 and 0.68 respectively), A8 (1.01 and 0.67), A12 (0.68 and 0.76) and A19 (0.35 and 0.46) characterized by low contamination level.

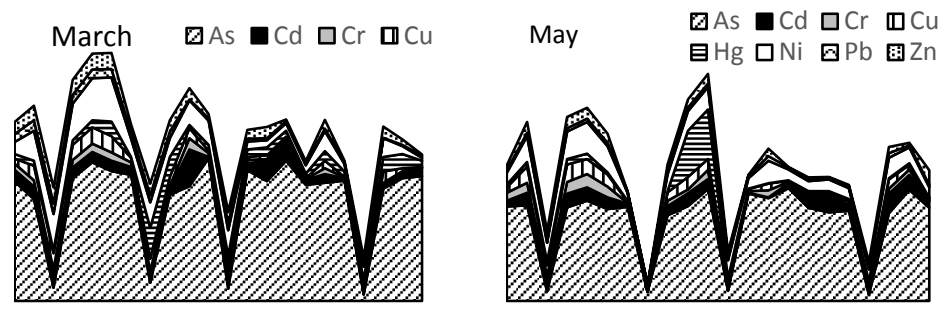

Fig. 3. Contamination factor $(\mathrm{Cd}, \mathrm{Zn}, \mathrm{Pb}, \mathrm{Ni}, \mathrm{Hg}, \mathrm{Cr}, \mathrm{As}, \mathrm{Cu})$ for sediments of the Olt River

Sediments of all sites are low contaminated $(C F<1)$ when discuss about $C r, Z n$ and $P b$. With few exceptions classified to moderate contamination level, $\mathrm{Cd}, \mathrm{Cu}$ and $\mathrm{Hg}$ exhibited values bellow 1 (low contamination). The $\mathrm{Ni}$ showed moderate contamination level in almost all the sites in the middle basin of the Olt River, and low contamination in the lower basin.

The index of geoacculation $\left(\underline{I_{G E O}}\right)$

The values of geoaccumulation index for $\mathrm{Cr}, \mathrm{Cu}, \mathrm{Zn}, \mathrm{Cd}$, and $\mathrm{Pb}$ in the Olt River revealed an unpolluted status (Fig. 4). For $\mathrm{Hg}$, the calculated $I_{g e o}$ values indicated that most of the investigated areas can be characterized as unpolluted ( $\left(I_{g e o}\right.$ $<0$ ), except for the sites A10 (Zăvideni) and A11 (Drăgăşani) where the pollution status (in May campaign) was moderately. The pollution status for $N i$ fluctuated from unpolluted to moderate polluted $\left(I_{g e o} 0-1\right)$ in case of five sites, A2 - A6, situated in the upper part of middle basin of the Olt River; however, the Igeo values for As described sediments as moderate to strong polluted $\left(1<I_{\text {geo }}<2 ; 2<I_{\text {geo }}<3\right)$, except for four sites, A3, A8, A12 and A19, were values below 0 are registered (non-polluted). Considering the influence of the Olt River and the antropogenic activity across the river before the Danube River, the results showed that on sampling site S12 (Danube River - upstream the Olt River) for all the heavy metals, the $I_{g e o}$ values were < 0, while at S14 (Danube River - downstream the Olt River) values higher than 2 (of 2.16 in March and 3.34 in May, respectively) were calculated for As.
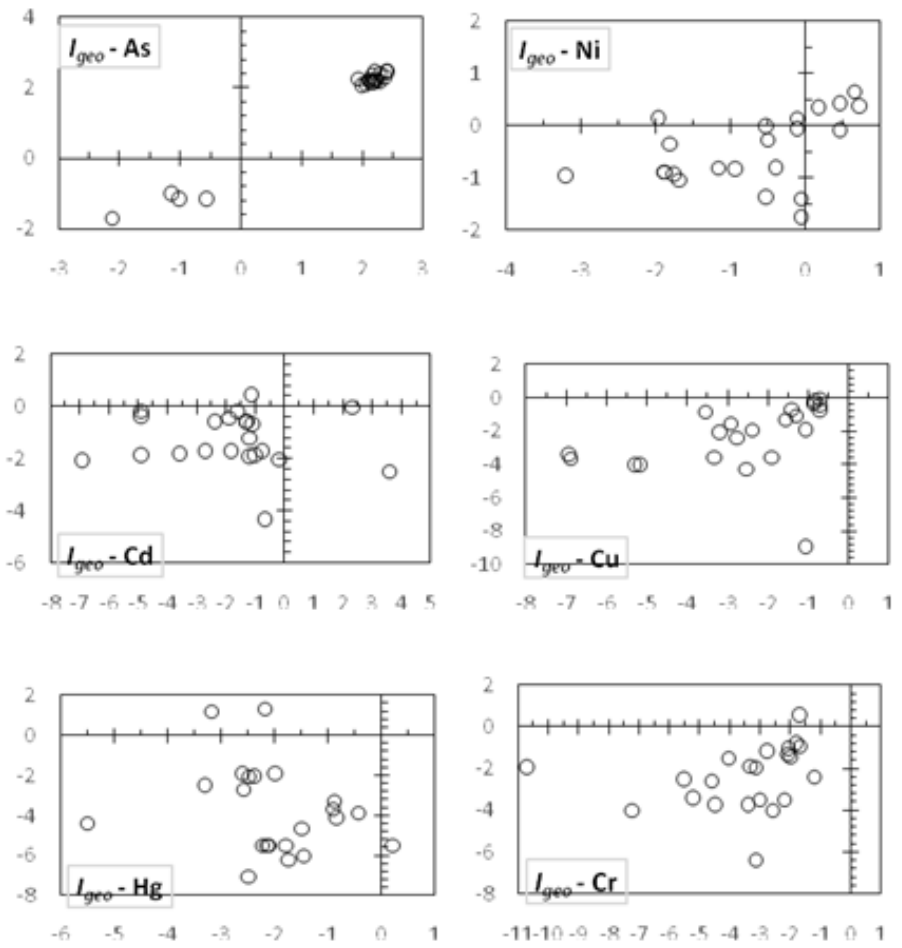

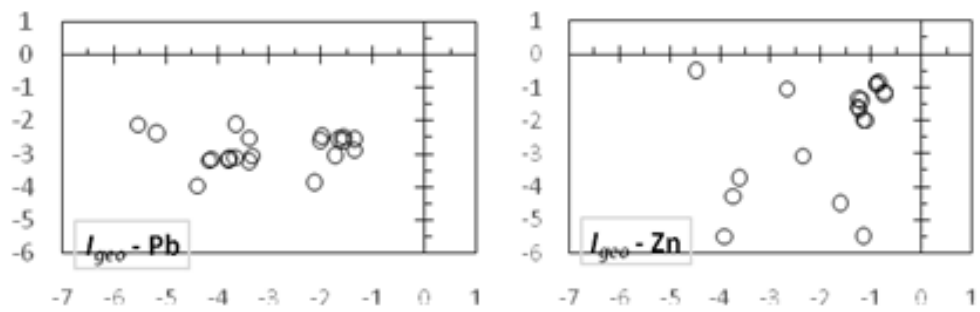

Fig. 4. Index of Geo-accumulation ( $\mathrm{Zn}, \mathrm{Pb}, \mathrm{Ni}, \mathrm{Hg}, \mathrm{Cu}, \mathrm{Cr}, \mathrm{Cd}$, and $\mathrm{As}$ ) for sediments of the Olt River

The modified degree of contamination $\left(m_{C H}\right)$ and degree of contamination $(\mathrm{CH})$

An intrinsic feature of the modified degree of contamination $\left(m_{C H}\right)$ was calculated to produce an overall average value for a range of pollutants. The modified degrees of contamination $\left(m_{C H}\right)$ for the sediments of the study area are shown in Fig. 5. The values ranged from 0.3 to 2.1 reflecting low to moderate degree of contamination; $71 \%$ from the sampling sites correspond to a very low degree of contamination changed. High values were found in the middle basin of the Olt River at stations S5 (Dăeşti), S10 (Zăvideni) and S11 (Drăgăşani).

Calculated contamination degree $(\mathrm{CH})$ values are highlighted in Fig. 6. According to the Hakanson (1980) classification, the $\mathrm{CH}$ values at 18 sites indicate a moderate degree of contamination, with values between 7.8 and 13.9. The highest $C H$ values were registered at sites S4-S6 ( $\min 12.4$, $\max 14.3), S 10(\min 11.92, \max 14.93)$ and $\mathrm{S} 11(\min$ 10.53 , max 16.8), that are in agreement with their corresponding high geoacumulation index for As, $\mathrm{Ni}$ (in case of S4S6) and $\mathrm{Hg}$ (for S10-S11).
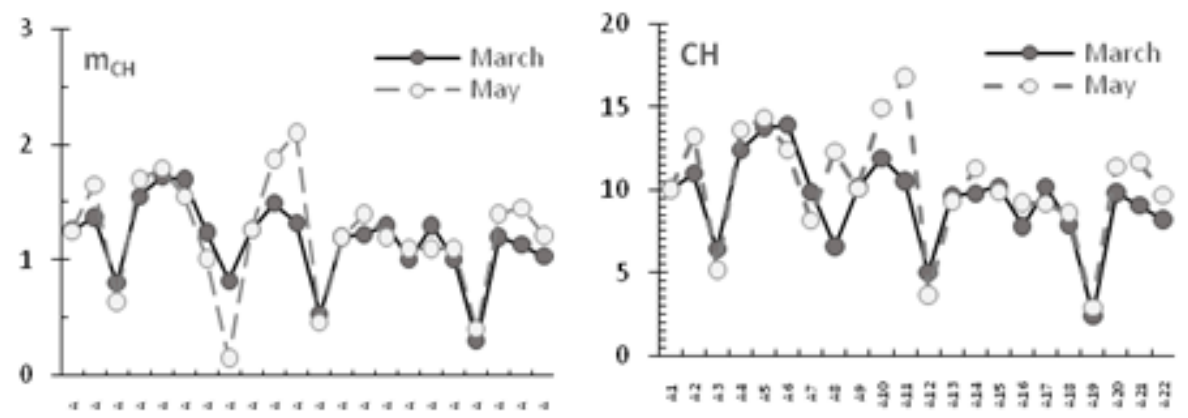

Fig. 6. The modified contamination $\left(m_{\mathrm{CH}}\right)$ and the degree of contamination $(\mathrm{CH})$ for sediments of the Olt River

\section{Pollution index (PLI) and pollution nemerow (PI)}

The $P L I$ values for heavy metals in the Olt River sediments are shown in Fig. 7, ranging from 0.21 to 1.18 with a mean value of 0.69 . At all sampling sites, the $P L I$ values were less than 1 , except for A4, A5, A6, A10 and A11 with $P L I$ greater than 1. All sampling sites suggest perfection (or no overall pollution), whereas A4-A6, A10 and a11 shows sign of pollution or determination of site quality. Relatively high PLI values at A4-A6, A10 and A11 suggests input from anthropogenic sources.

The Nemerow pollution indices indicate the polluted sites on the Olt River, $82 \%$ of them having a pollution index greater than 3 (Fig.7). This suggests heavy contamination by one or more elements at most of the sites, with the exception of the site A19 (non-polluted sediment) and A3, A8 and A12 (nearly to lighted polluted sediment). More importantly, the Nemerow pollution indices clearly indicate that most of the sites (with the exceptions of the site A3, A8, A12 and A19) have been polluted to some extent, with the most polluted areas at A1, A2, A4-A7, A9-A11, A13-A18, and A20A22. The major source of that contamination, is $H g$ and $A s$ for site A10 and A11 and As for the other sites.
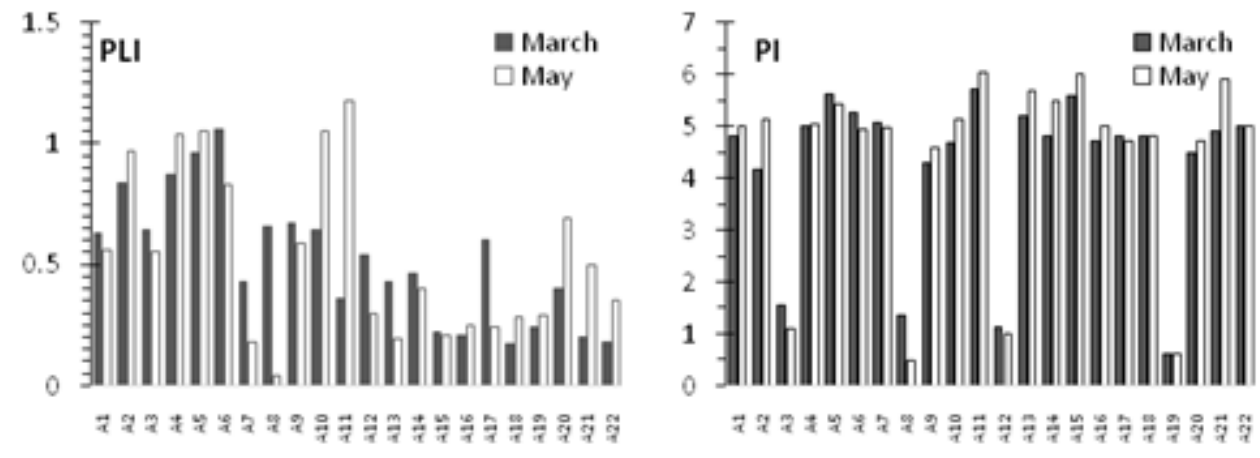

Fig. 7. Pollution Index (PLI) and Pollution Nemerow (PI) for sediments of the Olt River 
Potential ecological risk index (RI) and risk assessment code (RAC)

The potential ecological hazard index integrates the concentration of heavy metals with ecological effect, environmental effect, and toxicology. It is used to assess the heavy metals pollution and ecological hazard for sedimentology. The appraisal indices of heavy metal pollution and their relationship with pollution degree and potential ecological risk degree $\left(E_{f}\right)$ are highlighted in Fig. 8. It was found that the single risk indices $\left(E_{f}\right)$ of heavy metals were ranked in the order $\mathrm{Cr}<\mathrm{Zn}<\mathrm{Cu}<\mathrm{Pb}<\mathrm{Ni}<\mathrm{Hg}<\mathrm{Cd}<\mathrm{As}$. The values of ecological risk $\left(E_{f}\right)$ corresponding to $H g$ in the sites A10 and A11, in May 2018, were 137.3 and 147.3, indicating that $H g$ induce a very high risk to the local ecosystem and this should be of widely concern.

In order to quantify the overall potential ecological risk of heavy metals in sediments, the values of potential ecological hazard index (RI) were determined (Fig. 9). For 21 sampling sites the $R I$ values ranged from 7.9 to 113.3, posed low risk. The higher $R I$ values were observed at A10 and A11 sites, in May 2018 (216.8 and 228.17, respectively), attributed to moderate potential ecological risk level. These higher values may be due to the presence of higher content with $\mathrm{Hg}$.

The risk assessment code (RAC) was further used to assess the risk and mobility of the non-stable chemical fraction of heavy metals. The results of the environment risk assessment according to RAC are also given in Fig 9. According $R A C$ a high and very high environmental risk was estimated for $A s$ in most sections studied, except in sections A3, A12 and A19 where a low risk was estimated. There is no risk with $\mathrm{Hg}$ and $\mathrm{Cd}$, there is a low and medium risk with $\mathrm{Ni}, \mathrm{Cu}$ and $Z n$.
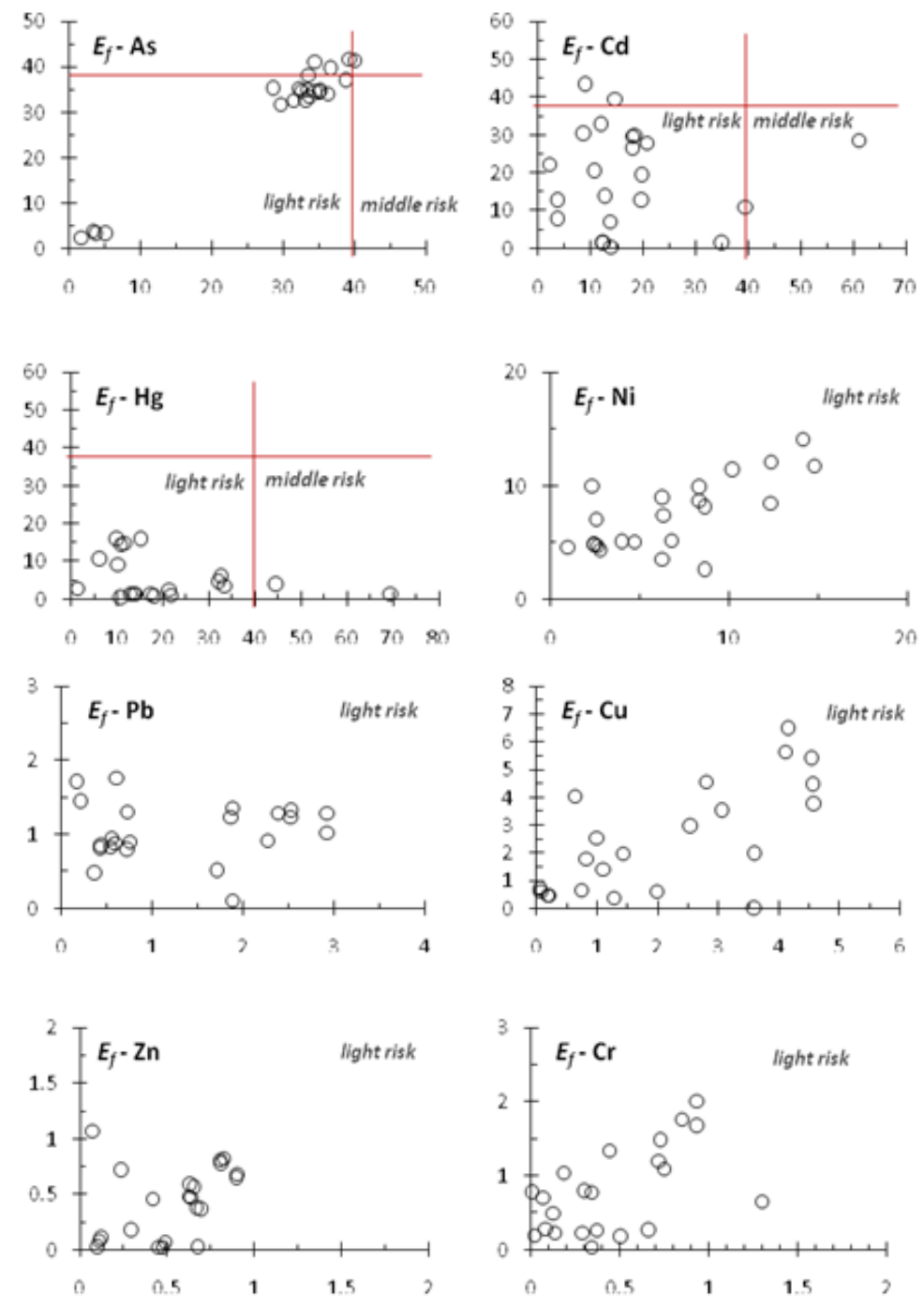

Fig. 8. Potential ecological risk index $\left(E_{f}\right)$ for sediments of the Olt River

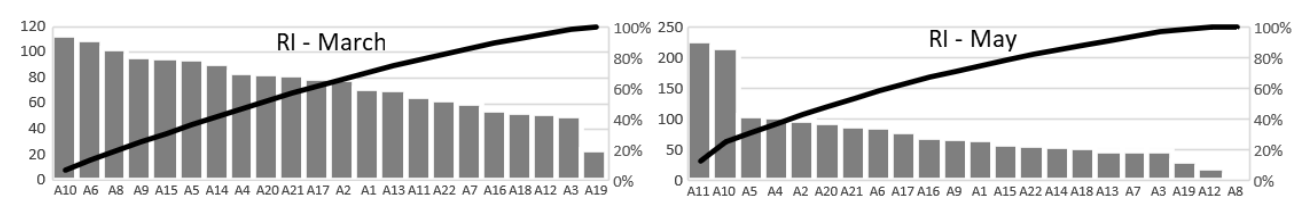




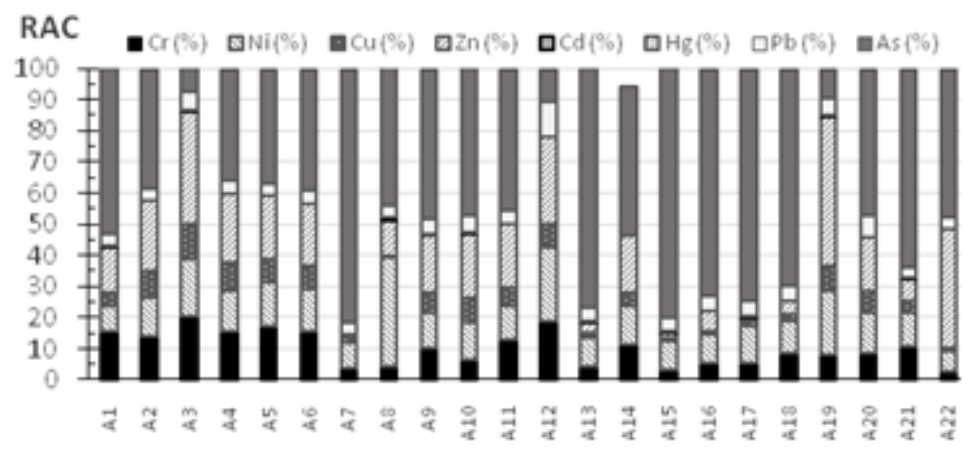

Fig. 9. Ecological Risk Index (RI) and Risk assessment code (RAC) for sediments of the Olt River

\section{Conclusions}

In this study, a methodology to assess the pollution with heavy metals ( $\mathrm{As}, \mathrm{Cd}, \mathrm{Cr}, \mathrm{Cu}, \mathrm{Ni}, \mathrm{Pb}, \mathrm{Hg}$ and $\mathrm{Zn}$ ) in surface sediment of the Olt River in its middle and lower basin was investigated. The results illustrated that $A s$ concentration in the sediment samples was considerably higher than the average shale values and may pose considerable ecological risk in sediment of the Olt River.

Therefore, several methods for ecological risc evaluation $\left(C F, I_{g e o}, R I, P L I, P I\right.$ and $\left.R A C\right)$ were introduced. The results showed that to all sites $A s$ had the highest $C F$ s reflecting highly contaminated sediments. Also, sediments of all sites are moderately contaminated with $N i$. The evaluation of $I_{g e o}$ also revealed that the sediments were moderate to strong polluted with $A s$. Similar conclusion was draw when applied the pollution coefficient $E_{f}$. The $R A C$ confirmed the results of $R I$ and $I_{g e o}$; as heavy metals, $A s$ was the most important factor affecting the ecological environment of the Olt River lakes. Important strategies should be implemented to reduce the discharge of industrial wastewater since the As mainly originate from industrial sources.

Acknowledgments: Acknowledgment-ul nou este: "This study has been financed by the Romanian Ministry of Education and Research, National Authority for Scientific Research, NUCLEU Program, under Project PN 18120303 "Assessing the impact of waste water discharges on the environment through advanced analytical investigations based on nuclear and other related techniques" and Project PN 19110303 "Advanced techniques for identifying sources of contamination and biochemical reactions in aquatic ecosystems".

\section{References}

1.X. KE, S. GUI, H. HUANG, H. ZHANG, C. WANG, and W. GUO, Chemosphere, 175, 473-481(2017).

2F. LI, J. HUANG, G. ZENG, X. YUAN, X. LI, J. LIANG, X. WANG, X. TANG, and B. BAI, J Geochem Explor., 132, 75-83 (2013).

3E. PERTSEMLI and D. VOUTSA, J. Haz. Mat., 148, 529-537 (2007).

4L. Gao, Z. Wang and S. Li, J. Chen, Chemosphere, 192, 31-42 (2018).

5E. G. DIEZ, J. P. CORELLA, T. ADATTE, and F. THEVENON, Appl Geochem. 78, 1-11(2017).

6.Q. LIN, E. LIUA, E. ZHANG, K. LI, and J. SHEN, Catena, 145, 193-203 (2016).

7.H. MALVANDI, Marine Poll Bull, 117, 547-553 (2017).

8.A. ZAHRA. M.Z. HASHMI, R.N. MALIK, and Z. AHMED, Sci Total Environ., 470-471, 925-933 (2014).

9.G. SURESH, P. SUTHARSAN, V. RAMASAMY, and R. VENKATACHALAPATHY, Ecotoxicol Environ Saf., 84, 117-124 (2012).

10.S. SALOMON, V. JENNE, and M. HOENIG, Talanta, 57, 157-168 (2002).

11.R. THOMAS, Practical Guide to ICP-MS, NY, USA, Marcel Dekker, 2004.

12.A. AMMANN, Int J Mass Spectrom Ion Process, 42 (4), 419-427 (2007).

13.MESDR, 2006, Order of Ministry no. 161/2006.

14.J. P. BRADY, G. A. AYOKO, W. N. MARTENS, and A. GOONETILLEKE, Article in press, Marine Poll Bull, xxx (2014) xxx-xxx.

15.S. HAKRABORTY, T. BHATTACHARYA, G. SINGH, and J. P. MAITY, Ecotox Environ Safe Journal, 100, 61-68 (2014).

16.Z. BANU, MD. S. A. CHOWDHURY, MD. D. HOSSAIN, K. NAKAGAMI, J. Water Resource Prot., 5, 239-248 (2013).

17.S. NAZEER, MUHAMMAD Z. H., and R. N. MALIK, Ecol Indic., 43, 262-270 (2014).

18.G. QINGJIE, D. JUN, X. YUNCHUAN, W. QINGFEI, and Y. LIQIANG, J. China Univ. Geosci., 19 (3), $230-241$ (2008).

19.IORDACHE M., MEGHEA A., NEAMTU S., POPESCU L. R., IORDACHE I., Rev. Chim. (Bucharest), 65, no. 1, 2014 , p. 87 - 93.

20.IONESCU P., RADU V. - M., GYORGY D., DIACU E., Eev. Chim. (Bucharest), 65, no. 9, 2014, p. 1092 - 1095.

21.BURADA A., TOPA C. M., GEORGESCU L. P., TEODOROF L., NASTASE C., SECELEANU - ODOR D., ITICESU C., REV. CHIM.

(Bucharest), 66, No. 1, 2015, p. 48 - 54.

22.CIRTINA D., PASARE M., Rev. Chim. (Bucharest), 65, no. 6, 2014, p. 737 - 740.

23.J.-J. LIUA, Z.-X. NIA, Z.-H. DIAO, Y.-X. HUA, and X.-R. XUA, Marine Poll Bull, 128, 132-139 (2018).

24.T. YANG, H-J. HUANG, FA-Y. LAI, Trans. Nonferrous Met. Soc. China, 27, 2249-2259 (2017).

Manuscript received: 19.11 .2018 